\title{
What Does the Public Want Police to Do During Pandemics? A National Experiment*
}

\author{
Justin Nix University of Nebraska Omaha \\ Stefan Ivanov University at Albany, SUNY \\ Justin T. Pickett University at Albany, SUNY
}

Research Summary: We administered a survey experiment to a national sample of 1,068 US adults in April 2020 to determine the factors that shape support for various policing tactics in the midst of the COVID-19 pandemic. Respondents were sharply divided in their views about pandemic policing tactics, and were least supportive of policies that might limit public access to officers or reduce crime deterrence. Information about the health risks to officers, but not to inmates, significantly increased support for "precautionary" policing, but not for "social distance" policing. The information effect was modest, but may be larger if the information came from official sources and/or was communicated on multiple occasions. Other factors that are associated with attitudes toward pandemic policing include perceptions of procedural justice, altruistic fear, racial resentment, and authoritarianism. Policy Implications: When considered together with other evidence, one clear takeaway from our study is that the public values police patrols and wants officers on call, even during pandemics. Another is that people who believe the police are procedurally just are more willing to trust officers in times of crisis and to empower them to enforce new laws, such as social distancing ordinances. Our results thus support continued procedural justice training for officers. A third takeaway is that agencies must proactively communicate with the public about the risks their officers face when responding to public health crises or natural disasters, in addition to how they propose to mitigate those risks. They must also be amenable to adjusting in response to community feedback.

Keywords: policing, COVID-19, legitimacy, public opinion, deterrence, public health

\section{Introduction}

In January 2020, the World Health Organization identified a new coronavirus, COVID-19, which has since spread rapidly throughout the world. By March, they had classified it as a global pandemic. At the time of this writing, the virus has infected over 29 million people worldwide and claimed the lives of over 930,000. The United States has been hit especially hard, with over 6.5 million confirmed cases and 195,000 deaths (Centers for Disease Control \& Prevention, 2020). In the absence of a vaccine, the virus has caused significant societal disruptions to those not infected - including the cancellation of sporting events, festivals, and concerts; the suspension of in-person K-12 and college classes; closure of non-essential businesses; and in many places, orders from government officials to

\footnotetext{
${ }^{*}$ This is the authors' post-print (CC-BY-NC-ND 4.0). Final version published in Criminology E⿱ Public Policy (Accepted 11/8/2020); Corresponding author: jnix@unomaha.edu.
} 
stay at home and practice "social distancing." The shutdowns have had dire economic consequences. In May, the US Labor Department reported that 36.5 million Americans had filed for unemployment in the previous eight weeks. Such abrupt changes to citizens' daily lives have major consequences for the criminal justice system (Jennings \& Perez, 2020; Lum et al., 2020).

The police, in particular, are faced with three primary concerns. The first is that, like everyone else, officers are at risk of contracting COVID-19. In New York City, a hotspot for the virus, over 5,000 members of the NYPD had tested positive, and 41 had died, as of early May (Rummler, 2020). The Detroit Police Department was similarly ravaged by the virus: $6 \%$ of uniformed officers tested positive - including the Chief - and nearly $36 \%$ were quarantined at some point (Eligon \& MacFarquhar, 2020). Such alarming statistics, coupled with a shortage of personal protective equipment $(\mathrm{PPE})^{1}$, suggest a need for precautionary policing - that is, cutting back on self-initiated activities and enforcement of low-level crimes. Indeed, a survey of approximately 1,000 police departments conducted in March revealed that $61 \%$ had "adopted formal policies to reduce or limit proactive traffic or pedestrian stops" (Lum et al., 2020). For example, the South Burlington (VT) Police Department instructed officers to limit proactive traffic stops to "more serious violations." Meanwhile, Gloucester Township (NJ) police officers were told "pedestrian contacts and stops will only be conducted when necessary for public safety or caretaking purposes." ${ }^{2}$ In theory, de-emphasizing these sorts of enforcement activities should protect both officers and citizens by providing fewer opportunities for the virus to be transmitted.

A second, related concern for the police is reducing jail populations. Many states have made conscious efforts to reduce jail and prison populations to avoid the spread of COVID-19 among inmates (Nowotny et al., 2020; Saloner et al., 2020). Here again, precautionary policing is one obvious way to do this. As but one example, the Rockford (IL) Police Department ordered its officers to issue Notices to Appear, rather than making custodial arrests, for misdemeanor crimes in the interest of reducing the jail population. Even where police departments have not instructed their officers to minimize self-initiated contact with citizens, the courts might nevertheless induce officers to cut back on arrests by changing bail requirements or refusing to prosecute certain offenses. Similarly, correctional facilities may adopt policies limiting the types of arrestees they will

\footnotetext{
${ }^{1}$ See, for example, https://www.policefoundation.org/covid-19/\#Dashboard.

${ }^{2}$ See https://www.policeforum.org/covid-19-response.
} 
admit. According to Lum et al. (2020, p. 1), 65\% of responding agencies "noted that the jail or correctional facility that intakes agency arrestees had already restricted the types of arrestees it would receive because of COVID-19 (e.g., misdemeanors or those who seemed ill)." Thus, whether due to departmental guidance or in response to policies adopted by the courts and/or correctional system, police officers find themselves using more discretion about who they arrest for low-level offenses in the midst of the pandemic.

The third concern is quite different from the previous two. In some places, such as New York City, police were directed to enforce social distancing ordinances (e.g., stay at home orders, no large gatherings). Though in the interest of public health, it was fiercely opposed by the Police Benevolent Association (the union representing NYPD officers), which called social distancing enforcement "untenable" and warned that "police officers should be allowed to focus on our core public safety mission," or "the city will fall apart before our eyes" (Axelrod, 2020). Additionally, social distancing enforcement gives officers discretion to police new types of offenses (e.g., gathering in public, not wearing a mask), which carries the potential for racial disparities. In the Brooklyn Borough, officers arrested 40 people for social distancing violations from March 17th to May 4th - 35 of whom were Black (Southall, 2020; Kaste, 2020). Social distancing enforcement is also opposed by some segments of the general population, who see it as government interference with their individual liberties, and who have begun protesting and filing lawsuits in response (Hoskin, 2020; Mervosh et al., 2020).

Several critical but as yet unanswered questions remain. One is simply: what sort of policing does the public want during the pandemic? It is the public, after all, who empower the police to do their jobs (Sunshine \& Tyler, 2003), whose trust is necessary for effective policing (Peyton et al., 2019), and whose attitudes determine the sustainability of criminal justice policy and practice (Pickett, 2019). In fact, it appears that public pressure may be deterring officers from enforcing social distancing in some areas (Phillips, 2020). If the public is informed about the health risks for officers of policing during a pandemic, will they support pulling back on traditional enforcement? Would information about the health risks to jail and prison inmates have similar effects? Or, will the public be less able to "empathetically identify" (Unnever \& Cullen, 2009, p. 284) with inmates than officers? How will different types of health-risk information affect views about social distance policing? 
Another important question is: who is most supportive of precautionary and social distance policing? Prior research provides clues about how people might perceive precautionary policing and social distancing enforcement. For example, because social distance policing may give officers more discretion to enforce new offenses, whites and those who perceive police as procedurally fair may be more supportive (Weitzer \& Tuch, 2006; Wolfe et al., 2016). We might also expect that factors that increase punitiveness in general, such as racial resentment, authoritarianism, and conservativism, will also foster opposition to allowing police to "pull back" in the name of public health. Indeed, general punitiveness is a strong predictor of support for aggressive policing (Johnson \& Kuhns, 2009; Pickett, 2016; Silver \& Pickett, 2015). Alternatively, for both rational and altruistic reasons, those who are more fearful of contracting the virus, or concerned about others getting sick, might be more supportive of precautionary and social distance policing. We know that both personal fear and altruistic fear influence precautionary behaviors in other contexts (Drakulich, 2015; Warr \& Ellison, 2000).

To begin answering some of these questions, we conducted an experiment with a nationwide survey of 1,015 US adults in April 2020, soon after most states issued lockdown orders and police agencies began grappling with how to enforce social distancing ordinances. Respondents were randomly assigned to either receive no relevant information (control group) or to receive information about COVID-19's threat to police health or inmate health. They were then asked a series of questions about how the police should function during the COVID-19 pandemic. We also measured theoretical predictors. Results suggest that the public is split on how officers should police pandemics, that information about officer health risks increases support for pulling back on traditional enforcement, and that two consistent and strong predictors are racial resentment and altruistic fear. Racially resentful respondents tend to oppose pandemic-based changes in policing, whereas altruistically fearful respondents tend to support changes.

\section{How to Police Pandemics: An Open Question}

The function of police during a pandemic - just as in the absence of a pandemic - is to protect the community (Bittner, 1970), but the pandemic adds a new threat to public safety besides crime and disorder: a deadly virus. The world has not experienced a pandemic like COVID-19 since the 1918 
Spanish Flu - long before sociological inquiries of policing were common. However, the disaster response literature is rife with examples of how local police departments adapt to natural disasters (Drabek, 1985; Drabek \& McEntire, 2002; Rojek \& Smith, 2007). In their review of the literature, Bonkiewicz and Ruback (2012) observed:

Law enforcement agents may change their style of policing in disasters to respond not only to the physical impact of the event but also the social impact, including the perceptions, beliefs, and behaviors of citizens. Put simply, how citizens respond to disasters... affects officers' style of policing (p. 144).

Specifically, they noted three disaster stages - approach, onset, and recovery - and proposed that citizen priorities and behaviors during each of these stages dictate which "style" of policing is most appropriate (i.e., Wilson (1978)'s Legalistic, Watchman, and Service styles). The "Watchman" style of policing is best suited for the onset of a disaster, they contended, because of its emphasis on order maintenance, increased officer discretion, and enforcement flexibility. All of these components of Watchman policing, however, may concern people who are worried about police discrimination and may create police-community tensions.

During the onset of the COVID-19 pandemic, consistent with the recommendation to use Watchman policing in disasters, officers in many US jurisdictions were given the discretion to enforce new types of public health offenses (see e.g., Phillips, 2020) while simultaneously being instructed to pull back from enforcing traditional offenses (Lum et al., 2020). Importantly, criminal activity did not simply cease to be a problem once many Americans were under stay-at-home orders (Ashby, 2020; Campedelli et al., 2020; Mohler et al., 2020). In fact, homicides have increased in twenty-five major cities (Abt et al., 2020). As a result, police departments were forced to balance their new responsibilities with traditional activities (e.g., traffic enforcement, foot patrols, criminal investigations), all while their officers were at risk of contracting the virus from community members. Notably, they juggled these responsibilities in the absence of knowledge concerning community expectations of them during the onset of COVID-19.

Therefore, a key question is whether the public supports either precautionary or social distance policing during pandemics. As Meares and Tyler (2020) emphasize, the first question in policing must always be: what does the public want? An equally important question is: what would the 
public want if it was informed? In general, the public has very little knowledge about the criminal justice system (Pickett et al., 2015; J. Roberts \& Stalans, 1997) or about the conditions in prisons and jails (J. V. Roberts \& Hough, 2005; Travis et al., 2014; Wozniak, 2014). This is because, lacking relevant direct or vicarious experience, most citizens get criminal justice information from news media depictions (Shi et al., 2020), which are notoriously inaccurate (Dorfman \& Schiraldi, 2001; J. Roberts \& Stalans, 1997; Surette, 2011). However, the public often does change its attitudes after acquiring accurate information (Indermaur et al., 2012; Larsen \& Olsen, 2020; J. Roberts et al., 2012). This suggests that exposure to reliable information about pandemics may affect how citizens want officers to police them.

In the context of the COVID-19 pandemic, some media sources provided accurate information about the virus, but others did not (Bridgman et al., 2020; Jamieson \& Albarracin, 2020). However, much less information was available about the virus's criminal justice consequences. As the toll on the criminal justice system became deadlier and more pressing, some news outlets began to cover the pandemic's effects on police and inmates (e.g., Bates, 2020; Elinson, 2020; Giorgis, 2020; Board, 2020). Although it is unlikely that most Americans would have anticipated the virus's effects on police departments and correctional facilities, information about those effects, through empathetic identification with officers and inmates, may change their attitudes about pandemic policing.

\section{Additional Sources of Attitudes Toward Pandemic Policing}

Beyond accurate information about the criminal justice consequences of COVID-19, there are other theoretical sources of attitudes toward pandemic policing styles. These include factors affecting views about the police generally, about crime generally, and about the importance of controlling the spread of the virus. We discuss each below.

\section{Perceived Procedural Justice}

People want to be treated justly by legal authorities, and their perceptions about whether they receive fair treatment strongly influence their attitudes toward those authorities, toward the law as a whole, and toward specific criminal justice policies and practices (Tyler, 2004; Tyler \& Jackson, 2014). In the policing context, people express more satisfaction and trust in police officers who are 
procedurally just - that is, those who explain their decisions, listen to citizens, are unbiased and fair, and show genuine care and concern about people (Tyler, 2006). When individuals perceive greater police procedural justice, they are more likely to accept officers' decisions, cooperate with the police, and bestow legitimacy on the broader institution of policing (Hinds \& Murphy, 2007; Jackson et al., 2012; Maguire et al., 2017; Mazerolle et al., 2013; Tankebe et al., 2016; Wolfe et al., 2016).

Pandemic policing puts faith in officers to use their enormous discretion both to enforce new, controversial and ambiguous types of offenses, such as congregating in large groups or refusing to wear a mask in public, and to pull back on enforcing certain traditional offenses (Jouvenal \& Brice-Saddler, 2020). Agencies in some cities faced backlash when evidence emerged that officers were disproportionately enforcing social distancing against poor and minority citizens (Southall, 2020). On a few occasions, officers were observed using force on citizens who were not abiding by social distance ordinances (Moore \& T, 2020; Stelloh, 2020). Giving officers discretion to enforce these new ordinances clearly invites the opportunity for unfair treatment and abuse of power, as does allowing them to decide not to enforce other traditional offenses, which they may choose to continue enforcing only against certain types of people. Nevertheless, these policies may be deemed necessary in the interest of public health. Past research shows that people who perceive the police as procedurally just, and thus as more legitimate, are more willing to empower them to engage in invasive or coercive tactics (Fox et al., 2020; Moule Jr et al., 2019; Sunshine \& Tyler, 2003).

\section{Racial Resentment and Authoritarianism}

Precautionary policing and social distance policing both entail a shift of enforcement away from traditional crime-control: precautionary policing entails less enforcement while social distance policing entails focusing on a new type of offense that is separate from street crime. Factors that increase concern about street crime (e.g., theft, drugs, violence) and punitiveness toward criminals might increase opposition to pandemic policing, if individuals perceive changes in enforcement as facilitating crime by passively condoning it, as with precautionary policing, or by diverting resources from its prevention, as with social distance enforcement. Theoretically, two factors are particularly applicable here: racial resentment and authoritarianism. 
Racial resentment is a modern form of racism that centers on a denial of discrimination and a conviction that Black citizens are undeserving of special government assistance (Henry \& Sears, 2002; Kinder et al., 1996). It is one of the most consistent and strongest predictors of punitive attitudes (Brown \& Socia, 2017; Pickett \& Baker, 2014; Unnever \& Cullen, 2010). This association reflects the "racial typification" of crime, which draws a nexus between street crime and minorities - particularly young, Black men - in the minds of American citizens (Chiricos et al., 2004; Muhammad, 2010). Insofar as support for aggressive policing is akin to punitiveness, as it appears to be (Johnson \& Kuhns, 2009; Pickett, 2016; Silver \& Pickett, 2015), racial resentment should reduce support for pandemic policing styles that involve officers either pulling back from enforcement or shifting their focus to new, non-street crime offenses.

Authoritarianism may also reduce support for pandemic policing. Authoritarians are concerned with enforcing the traditional moral order and ensuring obedience to authorities (Gerber \& Jackson, 2013; Tyler \& Boeckmann, 1997), and tend to be more punitive (Brown \& Socia, 2017; Unnever \& Cullen, 2010). Moral Foundations Theory (MFT) provides a useful conceptualization of authoritarianism (Haidt, 2012), and helps explain its relevance to criminal justice attitudes (Silver, 2017). Broadly, MFT suggests that individuals possess different domains of moral intuitions, called moral foundations, which have their basis in evolution, but which are strengthened and shaped though socialization (J. Graham et al., 2009; Haidt, 2012). These moral foundations lead individuals to perceive certain behaviors as either virtuous or transgressive (J. Graham et al., 2009), and each foundation increases concern about specific types of deviance (Silver, 2017). The authority/respect foundation "promotes intuitions that obedience and deference to authority, social hierarchies, and social customs are virtuous whereas disrespect and disobedience are moral transgressions" (Silver, 2017, p. 416). This foundation should promote opposition to policing styles that divert attention and resources away from enforcement of traditional threats to the moral order. ${ }^{3}$

\footnotetext{
${ }^{3}$ If there was a consensus among US authorities about social distancing, authoritarians might view it in moral terms. No such consensus exists, however. The director of the Office of National Intelligence, for example, put a photo of the Bill of Rights on social media and wrote: "Signed Permission Slip to Leave Your House" (Sommer et al., 2020). President Trump also has refused to wear a mask, has held large gatherings (e.g., rallies), has praised protests of lockdown orders, and has called for re-opening the country.
} 
Personal and Altruistic Fear of COVID-19

Many Americans are personally afraid of being infected with COVID-19, so afraid that they have suffered mental health consequences (Fitzpatrick et al., 2020). Many more are altruistically afraidthat is, they are worried about other people, such as their family members and friends, becoming infected with COVID-19 (Sloan et al., 2020). Prior research shows that both personal and altruistic fear often lead to defensive and protective behaviors (Drakulich, 2015; Warr \& Ellison, 2000). Some studies have found that fear of other types of public safety threats, such as crime, terrorism, and social breakdown influence views about policing and social control (Huddy et al., 2005; Jackson \& Bradford, 2009; Pickett, 2016).

\section{The Current Study}

To provide a preliminary understanding of public preferences for policing during the COVID-19 pandemic, as well as to assess the role of information exposure on these preferences, we surveyed members of the American public about their attitudes towards various policing practices that have been central to discussions of policing in the context of the novel coronavirus. While we discuss the specifics of our survey experiment in more detail below, we developed the following hypotheses based on our review of the relevant literatures:

H1. Information about COVID-19's negative effects on officers and inmates will increase public support for precautionary and social distance policing.

H2. Those who perceive the police as procedurally just will also express greater support for both precautionary and social distance policing.

H3. Racially resentful people will be less supportive of both precautionary and social distance policing.

H4. Authoritarianism will reduce support for both precautionary and social distance policing.

H5. Personal and altruistic fear of infection will increase support for both precautionary and social distance policing. 


\section{Data and Methods}

To test our hypotheses, we embedded an experiment in an online survey that was administered to a nationwide sample of adult U.S. citizens $(\mathrm{N}=1,068)$ between April 15, 2020 and April 19, 2020. Researchers now use online samples regularly to examine public attitudes toward the police (Celestin \& Kruschke, 2019; Hamm et al., 2017; Mummolo, 2018; Pickett et al., 2018), toward procedural justice (Pedersen et al., 2017; Tyler et al., 2014), and toward criminal justice policies (Gerber \& Jackson, 2013; Gottlieb, 2017; Silver, 2017; Vaughan et al., 2019). Many online samples come from Amazon's Mechanical Turk (MTurk) (e.g., Gottlieb, 2017; Hamm et al., 2017; Mummolo, 2018; Silver, 2017), and for good reason. Studies have found that MTurk respondents provide high quality self-reports (Anson, 2018; Weinberg et al., 2014), and that experimental findings from MTurk samples almost always generalize to the US population (Coppock, 2019; Mullinix et al., 2015; Weinberg et al., 2014). ${ }^{4}$ For these reasons, we used MTurk to field our survey.

Following the current best practices to ensure data quality, we restricted our survey to MTurk workers who had an approval rating on prior Human Intelligence Tasks (HITs) of at least 95\% (Peer et al., 2014). Additionally, we required that respondents had completed at least 50 HITs, so that they had a reliable approval rating, and were residents of the United States. We also included two attention checks in the questionnaire, which were passed by the vast majority of respondents. We ran supplemental analyses of our main models excluding those who failed one or both of the attention checks (reported below). Table 1 provides the sample descriptive statistics, by experimental condition. Compared with the U.S. population, the respondents in each experimental condition are whiter, younger, better educated, and more likely to be male, which is normal in MTurk surveys (Levay et al., 2016; Thompson \& Pickett, 2019). Across the experimental conditions, respondents' characteristics are similar (see Table 1). ${ }^{5}$

\footnotetext{
${ }^{4}$ That said, MTurk can break down in observational studies that fail to measure (and control for) the factors influencing selection. These include age, gender, race and ethnicity, income, education, marital status, religion, ideology, and partisanship (Levay et al., 2016). Experimental studies like ours are less affected by this (Mullinix et al., 2015; Weinberg et al., 2014), because random assignment ensures internal validity (on expectation), and selection variables do not appear to moderate treatment effects to a substantial degree (Coppock, 2019). As Coppock et al. (2018) explain, there tends to be "low treatment effect heterogeneity in these types of standard social science survey experiments" (p. 12441).

${ }^{5}$ An anonymous reviewer correctly pointed out that access to technology can influence results from online surveys. In our case, however, it is not clear that differences in access to technology would result in selection bias, given that we measured and controlled for factors such as age, race, and income. In other words, under the assumption that technology usage mediates the effects of demographic factors on sample selection, the use of an Internet sample would
} 
[Table 1 here]

\section{Experimental Procedure}

We randomly assigned respondents to one of three experimental conditions: control, policing, or incarceration. All participants received the following introductory text: "The CORONAVIRUS (COVID-19) is a highly contagious virus that first infected people in China in 2019 and has since spread to the United States and other countries around the world, resulting in a worldwide pandemic." Those in the control condition received no further information. Those in the policing and incarceration conditions received additional information. They were asked to "read a brief summary from the following article about the impact of the CORONAVIRUS pandemic [on POLICING / in PRISONS AND JAILS] in the United States."

To emulate a realistic scenario in which the public receives information from a veritable news source, respondents in the treatment conditions were shown a picture of the title section of an online news article about the impact of COVID-19 on policing or in prisons and jails (See Appendix A for reproduced images), followed by a brief synopsis of the information in the respective articles. The policing article came from Time magazine (Bates, 2020) and was titled: "Police Departments, Sheriff's Offices Across the U.S. Grapple with COVID-19's Impact on Public Safety - And Their Own." The summary read:

Police departments across the country have been struggling to adapt to changes due to the coronavirus pandemic. Police officers often have to interact with citizens in public places, which puts them at higher risk of contracting the coronavirus. The result is that many officers are getting the virus. In some places, as many as one in six officers is out sick or in quarantine.

The incarceration article came from the New York Times (Williams et al., 2020) and was titled: “'Jails Are Petri Dishes': Inmates Freed as the Virus Spreads Behind Bars,” with the subtitle,

not create a backdoor path between the included predictors and our outcome variables, as long as the model controls for those demographic factors that influence technology access. Levay et al. (2016) made a similar point when noting that "MTurk respondents do not appear to differ fundamentally from population-based respondents in unmeasurable ways. This suggests that MTurk data can be used ... if researchers measure and account for a range of political and demographic variables as needed" (p. 1, emphasis added). In our study, we account for most of the selection variables identified by Levay et al. (2016). 
"Some jails are releasing people to stem outbreaks, but critics say it is not happening quickly enough to save lives and resources." The summary read:

Many scholars are concerned that inmates are in danger during the coronavirus pandemic. Prisons and jails are often crowded and unsanitary. Many inmates are old, come from backgrounds of poverty, and have a history of poor healthcare. Some inmates suffer from respiratory problems and heart conditions. Practices to slow the spread of the virus - avoiding crowds, frequent handwashing, disinfecting clothing — are nearly impossible inside prisons and jails.

\section{Dependent Variables}

The dependent variables measure respondents' attitudes toward two types of pandemic-related policing policies (see Lum et al., 2020). We presented respondents with eight "proposals for POLICING during the CORONAVIRUS (COVID-19) PANDEMIC," and asked them to indicate how much they supported or opposed each ( $1=$ strongly oppose, $5=$ strongly support). The proposals covered the two dimensions of pandemic policing. Six entailed precautionary policing: (1) "Cutting back on police foot patrols"; (2) "Cutting back on policing of traffic offenses (e.g., speeding)"; (3) "Cutting back on policing minor drug offenses (e.g., possession)"; (4) "Cutting back on policing of minor property offenses (e.g., petty theft)"; (5) "Having police only respond to emergency (911) calls for assistance"; (6) "Having police focus their enforcement efforts mainly on violent crimes." Two involved social distance policing: (1) "Having police increase their enforcement of social distancing"; (2) "Having police break up large parties and large social gatherings." Table 2 provides the pairwise correlations between each of the items. An exploratory factor analysis with promax rotation revealed two factors, corresponding to precautionary policing (loadings: .551 to .696) and social distance policing (loadings: .727 and .748). The factor loadings were well above the .32 cutoff proposed by Tabachnick and Fidell (2001). Accordingly, we averaged the responses to the respective items to create two standardized mean indices: Precautionary Policing $(\alpha=.811)$ and Social-Distancing Policing $(\alpha=.781)$.

[Table 2 here] 


\section{Independent Variables}

We included several independent variables that are of theoretical interest to explaining public support for modifications to policing during the COVID-19 pandemic: perceived procedural justice; authoritarian morality; racial resentment; and personal and altruistic fear of the coronavirus. Procedural Justice is a mean index (factor loadings: .824 to $.874, \alpha=.947$ ) based on responses to seven items $(1=$ strongly disagree, $5=$ strongly agree) asking how police behave in interactions with civilians (e.g. "Treat people fairly"; "Clearly explain the reasons for their actions"; see Appendix B). We adapted these items from previous research examining procedural justice (Mazerolle et al., 2013; Pickett et al., 2018).

Authoritarian Morality is a mean index (factor loadings: .559 to .678 , alpha $=.748$ ) based on four items ( $1=$ strongly disagree, $5=$ strongly agree $)$ asking about the importance of obedience to authority and traditions (e.g., "Respect for authority is something all children need to learn"; "When the government makes laws, those laws should always respect the traditions and heritage of the country"; See Appendix B). The items are adapted from J. Graham et al. (2009), where they were used to measure the authority foundation, and are similar to those used in other studies to measure this dimension of morality (Silver, 2017).

Racial resentment is a mean index (factor loadings: .690 to $.822, \alpha=.876$ ) based on five items ( 1 = strongly disagree, $5=$ strongly agree) adapted from Henry and Sears (2002)'s "Symbolic Racism 2000" scale. Examples of the items include: "Irish, Italians, Jewish, and many other minorities overcame prejudice and worked their way up. Blacks should do the same without any special favors"; "It's really a matter of some people not trying hard enough; if Blacks would only try harder they could be just as well off as Whites" (see Appendix B). All of the items have been used in other studies to measure racial resentment (Schutten et al., 2020; Silver, 2017).

To measure Personal Fear and Altruisitic Fear of COVID-19, we adapted questions from A. Graham et al. (2020). The question for Personal Fear was: "How worried are you that you will become sick from the coronavirus?" The response options were: $1=$ Not worried at all, $2=$ not too worried, $3=$ somewhat worried, and $4=$ very worried. Altruistic Fear is a mean index (factor loadings: .765 to $.827, \alpha=.909)$ based on six items that asked how often $(1=$ very rarely, $5=$ very often) respondents worried about different groups of people becoming sick from the coronavirus: 1) 
"First responders, police, and correctional officers"; 2) "Your family members"; 3 ) "Your neighbors"; 4) "Doctors and nurses"; 5) "People across America"; 6) "Your friends."

\section{Control Variables}

We also controlled for a host of additional variables that prior research suggests may influence attitudes about criminal justice in the United States (Brown \& Socia, 2017; Silver \& Pickett, 2015; Unnever \& Cullen, 2010). These items include race (1= White); ethnicity (1=Hispanic); gender $(1=$ male); age in years; marital status $(1=$ married); education $(1=$ high school or less, $5=$ graduate degree); annual household income $(1=\$ 0-\$ 24,999,5=\$ 100,000$ or more $)$; employment status ( $1=$ employed full-time); political ideology ( $1=$ strong Democrat, $5=$ strong Republican); and family victimization in past five years $(1=$ Yes $)$. Finally, due to the widespread news coverage of the COVID-19 pandemic, and evidence that news media consumption is linked to attitudes about crime and punishment (Baranauskas \& Drakulich, 2018; Shi et al., 2020), we asked respondents how closely they had followed news about the pandemic ( $1=$ Not at all closely, $4=$ Very closely).

\section{Analytic Strategy}

First, we examine the level of support for each of the proposed policies. We then estimate multivariate models analyzing the main effects of the experimental manipulations as well as the independent and control variables. Given that both outcomes are continuous, we use OLS regression to estimate the models. In keeping with recommendations in the experimental literature (Freedman et al., 2008; Lin et al., 2013), we first estimate models for both outcomes with only the experimental manipulations included as predictors, and then estimate models including the other variables. Due to listwise deletion of cases with missing data on key variables, our analytic sample ranges between $\mathrm{n}=987$ and $\mathrm{n}=1,015$.

\section{Results}

Figure 1 displays the percentage of respondents who support or strongly support each pandemic policing style. Turning first to precautionary policing, a slight majority of the sample expresses support for having the police focus on violence (60\%) and de-emphasize drug (54\%) and traffic 
enforcement (53\%). However, only a minority of the sample expresses support for having officers do less foot patrol (37\%), respond only to 911 calls (36\%), and de-emphasize property crime enforcement $(30 \%)$. The most accurate interpretation, then, is that the respondents are lukewarm at best about precautionary policing - they are split on some policies, but opposed to others. The findings are similar for social distance policing. A slight majority of the sample supports having officers shut down large gatherings (55\%) and enforce social distancing ordinances (52\%). In other words, the respondents are sharply divided about whether officers should engage in social distancing enforcement. The next portion of our analysis sheds light on the factors explaining this divide.

[Figure 1 here]

Table 3 presents the results of OLS models that regressed each of the outcomes onto the experimental manipulations, without and then with the covariates. Model 1, the baseline model for precautionary policing, shows that informing respondents about the health risks of COVID-19 for police officers has a statistically significant and positive effect on their support for having officers pull back from enforcement of traditional offenses $(b=.203, \mathrm{p}=.001)$. The effect is significant even using a Bonferroni-corrected alpha of .0125 to account for the fact that we tested two manipulations with two experimental outcomes. The effect remains significant at conventional levels in Model 2, which includes the covariates $(\mathrm{b}=.170, \mathrm{p}=.021)$. By contrast, providing respondents information about the risks of COVID-19 for inmates does not have a statistically significant effect on support for precautionary policing, either in the baseline (Model 1) or full model (Model 2), and in both cases the coefficient is much smaller than that for the information about officer health risks. Apparently, then, concern for officers' but not inmates' safety causes members of the public to become more supportive of limiting traditional law enforcement activities, as they learn more about the criminal justice consequences of COVID-19.

Turning to the covariates in Model 2, we find support for some of our hypotheses but not others. First, contrary to our expectations, perceived procedural justice is not significantly related to support for precautionary policing. As hypothesized, however, respondents who are more authoritarian $(\mathrm{b}=-.152, \mathrm{p}<.001)$ and racially resentful $(\mathrm{b}=-.144, \mathrm{p}<.001)$ tend to be significantly less supportive of precautionary policing. Personal fear of being infected with COVID-19 is also significantly and negatively associated with support for precautionary policing $(\mathrm{b}=-.134, \mathrm{p}<$ 
.001), which is contrary to our expectations. However, those who expressed more altruistic fear about others being infected were significantly more supportive of such policing $(\mathrm{b}=.220, \mathrm{p}<$ .001), as we hypothesized. Finally, two control variables are significantly related to support for precautionary policing: White respondents tended to be more supportive $(\mathrm{b}=.181, \mathrm{p}=.021)$ and older respondents tended to be less supportive $(b=-.013, \mathrm{p}<.001)$.

[Table 3 here]

Models 3 and 4 in Table 3 present the results from regressing social distance policing onto the experimental manipulations, with and without the covariates. Unlike in the case of precautionary policing, we find no evidence that information about the health risks of COVID-19 for officers or inmates significantly affects attitudes toward social distance policing. Similarly, we again find mixed support for our hypotheses. Several of the covariates have significant associations with this outcome. As hypothesized, perceived procedural justice is significantly and positively associated with support for social distance policing $(\mathrm{b}=.113, \mathrm{p}=.002)$, as is altruistic fear $(\mathrm{b}=.303$, $\mathrm{p}<.001)$. Thus, respondents who believe police are fair and who are afraid for others' safety tend to be more willing to grant police discretion to enforce social distancing ordinances. Also as hypothesized, racial resentment is significantly and negatively associated with support for social distance policing $(\mathrm{b}=-.139, \mathrm{p}<.001)$. By contrast, neither authoritarianism nor personal fear have statistically significant associations with support for social distance policing, contrary to our hypotheses. Finally, three control variables are significantly associated with support for social distance policing: support tends to be lower among older respondents $(\mathrm{b}=-.005, \mathrm{p}=.015)$, republicans $(\mathrm{b}=-.057, \mathrm{p}=.047)$, and those with crime victims in their family $(\mathrm{b}=-.215, \mathrm{p}=$ $.003)$.

The final column in Table 3 provides z-scores for equality-of-coefficient tests, per Paternoster et al. (1998)'s formula. These tests provide evidence about which variables have effects on the two outcomes that differ significantly across models. Among the key independent variables, the most noteworthy findings are that authoritarianism and personal fear are both much more strongly related to support for precautionary policing than to attitudes toward social distancing enforcement. Those who are more authoritarian and afraid for their own safety tend to oppose allowing police to 
pull back from traditional enforcement, but do not differ significantly in their views about whether police should enforce social distancing ordinances.

\section{Supplementary Analyses}

We included two attention checks in the survey, which were passed by $78 \%$ and $91 \%$ of respondents, which is consistent with or better than passage rates in prior studies (Anson, 2018; Berinksy et al., 2014). Paying attention in surveys is necessary for receiving experimental treatments, but attention checks measure attention with error $(\mathrm{r}=.458$ for responses to the two checks in our survey), and full-sample findings are intent-to-treat effects (Aronow et al., 2019). Nonetheless, it is best practice is to stratify on attention. When we exclude respondents who failed one or both of the attention checks, the police-health manipulation has a similar effect ( $b=.170$ vs. .123 to .179$)$ on support for precautionary policing in the full model, but the significance level varies ( $\mathrm{p}=.021$ vs. .017 to .129), because the sample size changes. The findings for the inmate health manipulation are unchanged.

\section{Discussion}

How do Americans define public safety? How do they want their communities policed? The nature of American policing should hinge on the answers to these questions (Meares \& Tyler, 2020), because police effectiveness and the quality of police-community relations certainly do. In response to the COVID-19 pandemic, police agencies across the country redefined public safety to include social distancing, and pulled back on enforcement of traditional offenses (Lum et al., 2020). Officers made numerous arrests and issued thousands of citations to enforce social distancing (Jouvenal \& Brice-Saddler, 2020), evidence of racial discrimination quickly accumulated (Ross, 2020), dozens of lawsuits were filed challenging the constitutionality of stay-at-home orders (Harris, 2020), and anti-lockdown protests broke out across the country (Hoskin, 2020). All of this happened mostly in the dark as to whether any of the pandemic-related changes in policing were consistent with public expectations. Our study addressed this research void, providing the first evidence about public attitudes toward precautionary and social distance policing during the pandemic. 
Americans who responded to our survey were sharply divided in terms of their support for both precautionary and social distance policing. Slight majorities support social distancing policies. However, only a minority supported precautionary policies that would reduce police patrols - a key component of deterrence (Lum \& Nagin, 2017; Nagin et al., 2015) — or limit officers' responsiveness to civilians' calls for assistance. Prior studies have shown that Americans have great faith in the crime-control benefits of preventive, patrol-based policing (Metcalfe \& Pickett, 2018). Additionally, policing scholars have increasingly called for police to focus less on apprehension and more on crime prevention through focused patrol and service (Lum \& Nagin, 2017). Our findings are consistent with this general body of scholarship, suggesting that in pandemics, the public is willing to accept cuts in some types of enforcement, but not in preventative patrols or service. A fundamental American belief, it appears then, is that the police should always be "out there" on watch and on call.

Turning to our experimental findings, four are notable. First, brief exposure to information about the health risks of COVID-19 for police officers significantly increased support for precautionary policing. Second, this information did not significantly affect support for social distance policing. This indicates that the public may see enforcement of social distancing ordinances as involving a more difficult tradeoff between officer safety and the public health benefits of reducing virus transmission between civilians. Third, exposure to the inmate health prime did not significantly influence support for either pandemic policing style, suggesting that the public empathetically identifies less with criminal suspects than with officers, which is unsurprising. Fourth, all of the information effects in our study, whether statistically significant or not, were modest in size, suggesting that views about pandemic policing are largely rooted in more general attitudes - about policing, about the virus, about crime, and about race.

Our observational findings provide support for the police empowerment hypothesis (Fox et al., 2020; Sunshine \& Tyler, 2003). Regardless of the experimental prime they viewed, respondents who perceived greater police procedural justice were more supportive of giving officers discretion to enforce social distancing requirements. Agencies will need this support moving forward if the continued spread of the virus necessitates more aggressive social distancing policies. Indeed, in many cities, police leaders have expressed concern that "punishing people for not wearing masks... would put officers at the center of yet another fraught controversy" (Phillips, 2020, para. 6). In practical 
terms, this underscores the need to increase officers' use of procedural justice in their day-to-day interactions with the public (Nagin \& Telep, 2020), which are increasingly likely to be captured on camera and disseminated through social media (Parry et al., 2019). Quasi-experimental studies of one-day training programs in Chicago (Skogan et al., 2015) and Louisville (Schaefer \& Hughes, 2016) suggest improvement in officers' attitudes toward treating people with procedural justice. A two-site randomized-controlled trial of T3 (Tact, Tactics, and Trust) training delivered over several months in Tucson (AZ) and Fayetteville (NC) showed similar promise (McLean et al., 2020). Beyond the immediate impact of such training - including improved attitudes and in some cases, behaviors (see Owens et al., 2018; Wood et al., 2020) - agencies might also find that community perceptions improve in the long run. What our findings suggest is that the reservoir of public trust accumulated during ordinary times through procedurally just policing may be critical in times of crisis. A critical direction for future research, then, as Nagin and Telep (2020) emphasize, is examining the long-term impacts of police procedural justice.

We also found support for the altruistic fear perspective, which holds that fear for others is not only more common than personal fear, but also tends to be a stronger motivator of defensive and precautionary behavior (Drakulich, 2015; Warr \& Ellison, 2000). In our study, altruistic fear of others getting sick with COVID-19 was significantly and positively associated with support for both precautionary and social distance policing. In fact, the standardized coefficients (not shown) indicated that altruistic fear was by far the strongest predictor of support for both types of pandemic policing. To our knowledge, no previous study has examined the role of any type of altruistic fearof COVID-19, of crime, or of police violence - in shaping views about police policies or practices. Our findings suggest this is a regrettable oversight. It appears that concern for others, including for police officers, is an important factor influencing public attitudes about policing in America.

Additionally, we found that racial resentment has a sizable, consistent, and negative association with support for pandemic policing. Racial resentful respondents are more likely to oppose both precautionary and social distance policing. In other words, racists want police to stick with enforcing street crimes - the kinds of crimes stereotypically associated with Black people. This finding is consistent with prior work that suggest support for aggressive, crime-control-focused policing tends to reflect racialized punitiveness (Johnson \& Kuhns, 2009; Pickett, 2016; Silver \& Pickett, 2015). In other words, for racists, the importance of police as guardians of the racial hierarchy (Weitzer 
\& Tuch, 2006) does not diminish just because there is a pandemic threatening officer health and public safety.

Although modest in size, the information effect documented in our experiment provides valuable insight into public opinion regarding the activities police departments should be prioritizing during the pandemic. We provided respondents with only a short summary of a single news article. It is likely that providing them with greater information, especially from police sources, over a prolonged period of time would have a much larger effect. Thus, communicating the risks officers face is a promising strategy for increasing community support for alternative, precautionary approaches such as de-emphasizing traffic and pedestrian stops, property crime enforcement, and/or drug enforcement. It may even increase support among members of the community who might otherwise be opposed to such approaches (e.g., those who score higher on authoritarian morality and racial resentment).

Such support will be critical in the months ahead, as municipalities all over the United States brace for another wave of infections (Coyle \& Spencer, 2020). Agencies would be wise to leverage their relationships with the local media to push out information, as prior work suggests television news consumption increases confidence in and willingness to empower the police (Callanan \& Rosenberger, 2011; Roche et al., 2016). They should also consider regularly posting information updates on various social media platforms (Intravia et al., 2018). According to a Gallup poll conducted around the same time as our survey, $70 \%$ of Americans find public officials' social media posts about COVID-19 "moderately" or "very helpful" (Ritter, 2020). Data collected by the Pew Research Center suggests agencies can reach the biggest audience by posting on Facebook, though notably, Instagram and Snapchat are popular alternatives frequented by adults in the 18-29 age group (Perrin \& Anderson, 2019).

As they proactively push out information about the risks officers face and steps being taken to mitigate them, agencies will need to be mindful of the kinds of information they share, and remain open to adjusting in response to community feedback. In Louisville (KY), for example, Chief Steve Conrad issued a special order in mid-March which stated officers would no longer respond to most non-violent crimes requiring a police report (e.g., disorderly conduct, intoxicated persons, and certain burglaries; see Riley \& Ragsdale, 2020). Less than one month later, he reversed the 
special order, citing community concerns and "criminals taking advantage of the pandemic" (Vogt, 2020). Such is the challenge that comes with being transparent.

In the years ahead, there will also be a pressing need for research examining the long-term effects of the COVID-19 pandemic on officers, agencies, and the communities they serve. For example, the disaster response literature suggests officers working during the COVID-19 pandemic might be at heightened risk of experiencing post-traumatic stress disorder (Faust \& Ven, 2014). Likewise, there is reason to be concerned that enforcement of social distancing ordinances could have harmful effects on the mental health of community members, especially if officers disproportionately target minority communities (Geller et al., 2014; Geller et al., 2017), as initial stories suggest (Ross, 2020). At the organizational level, agencies will undoubtedly see their recruitment and retention efforts hampered by budget constraints in the wake of COVID-19 (as well as public pressure to "defund the police" following the killing of George Floyd in Minneapolis). This means we could see fewer police officers patrolling the streets of our cities in the coming years. Researchers must rise to the challenge of rigorously evaluating the relationship between police presence, policing tactics, and crime in communities.

\section{Limitations and Additional Directions for Future Reseach}

Several limitations of our study deserve further discussion. To begin, we surveyed a convenience sample of MTurk workers, our survey was cross-sectional, and we used news articles as the information sources. Studies have shown that experiments with MTurk typically are generalizable to the US population (Coppock, 2019; Mullinix et al., 2015; Weinberg et al., 2014). Additionally, as Mutz (2011) emphasizes, one-shot treatments in experiments like ours are assumed to persist in the real world because of recurring exposure to relevant information. It is also the case that much of the information the public receives does come from the media. Nevertheless, future studies should attempt to replicate our work with probability samples, and should examine the duration of treatment effects as well as how they vary with the information source (as respondents may vary in terms of how much they trust mainstream media outlets) and the frequency of exposure. Future work should also examine regional- or state-level variation in public attitudes, and consider alternative analytic strategies such as using a psychometric approach to construct response 
scales, collecting political spectrum data (to avoid the limitations of impression management in self-labelling), and/or using a multi-label classification approach to analyses. ${ }^{6}$

Another limitation of our study is that we measured personal and altruistic fear of contracting COVID-19 (A. Graham et al., 2020), but not fear of criminal victimization, which conceivably would also influence respondents' perceptions of what police should focus on during the pandemic. In fact, respondents would likely balance these fears against one another when thinking about what they want from the police. Note, however, that we did control for whether respondents or their family members had been the victim of a crime in the past 5 years, which prior research suggests is a strong predictor of fear of victimization (see e.g., Hale, 1996). In our sample, those who had been criminally victimized - or whose family members had been criminally victimized were significantly less supportive of social distance policing. However, criminal victimization was not significantly related to support for precautionary policing. This is preliminary evidence that the relationship between fear of criminal victimization and preferences for pandemic policing may be complex and may vary depending on the specific policy in question. Accordingly, future studies in this area should measure fear of criminal victimization in addition to pandemic-related fears.

Our inmate health prime did not directly communicate any implications for policing, which is one potential explanation for its null effects on respondents' attitudes toward precautionary and social distance policing. Future studies attempting to build on our work should ensure respondents are provided information about how efforts to reduce jail populations can affect policing and public health (e.g., the probability that some of those released will recidivate, or that community fear of crime - or contracting COVID-19 - could increase). Finally, by the time we administered our survey in mid-April, the general public was acutely aware of COVID-19 and its implications for societal norms (although many Americans and some politicians continued to believe conspiracy theories and/or downplay the virus's health risks; see A. Graham et al., 2020). What this means is that respondents' baseline knowledge may have diminished the impact of our police and inmate health primes. Though it seems unlikely that the public had a thorough understanding of the unique risks posed to police officers or inmates, this could be yet another explanation for some of our null findings.

\footnotetext{
${ }^{6}$ Our thanks to an anonymous reviewer for suggesting some of these potential avenues for future research.
} 


\section{Conclusion}

The COVID-19 pandemic has been, and continues to be, an unprecedented challenge for American policing. Yet, perhaps their most pressing task is to come up with an answer to the same fundamental question with which they have always grappled: what does the public want them to do? Our study uncovered modest support for social distance policing, and mixed support for various tactics which we have referred to as precautionary policing. More importantly, we found that providing the public with information about the health risks faced by officers during this pandemic can increase their support for precautionary policing. In a moment of intense public scrutiny of law enforcement, we hope that our findings will be useful for agencies to engender public support for policies that promote the safety and wellbeing of police officers as they continue to operate in the dangerous and uncertain context of the COVID-19 pandemic.

"Few doubt that major epidemics and pandemics will strike again and few would argue that the world is adequately prepared," (Fan et al., 2018, p. 129) explain. If the United States does experience another pandemic, after the current one abates, we hope our findings will be useful for considering the policing implications of those public health crises. Hopefully, however, the current COVD-19 pandemic will prove to be a once-in-a-lifetime event. If so, we hope our study will nevertheless serve as a preliminary evidentiary base for how the public wants police to respond to natural disasters and public health crises, and for how such preferences may diverge among different subgroups of Americans. 


\section{References}

Abt, T., Rosenfeld, R., \& Lopez, E. (2020). Covid-19 and homicide: Final report to arnold ventures. https:// craftmediabucket.s3.amazonaws.com/ uploads / COVID-19-Homicide_061520_ Final.pdf

Anson, I. G. (2018). Taking the time? explaining effortful participation among low-cost online survey participants. Research \& Politics, 5(3), 1-8.

Aronow, P., Baron, J., \& Pinson, L. (2019). A note on dropping experimental subjects who fail a manipulation check. Political Analysis, 27(4), 572-589.

Ashby, M. P. (2020). Initial evidence on the relationship between the coronavirus pandemic and crime in the United States. Crime Science, 9, 1-16.

Axelrod, T. (2020). Ny police union warns city will 'fall apart' if enforcement of social distancing does not end. The Hill. https:// thehill.com/homenews/state- watch/496221-ny-policeunion-warns-city-will-fall-apart-if-enforcement-of-social

Baranauskas, A. J., \& Drakulich, K. M. (2018). Media construction of crime revisited: Media types, consumer contexts, and frames of crime and justice. Criminology, 56 (4), 679-714.

Bates, J. (2020). Police departments, sheriffs' offices across the u.s. grapple with covid-19's impact on public safety - and their own. Time Magazine. https://time.com/5812833/coronaviruspolice-departments/

Bittner, E. (1970). The functions of the police in modern society: A review of background factors, current practices, and possible role models. National Institute of Mental Health, Center for Studies of Crime; Delinquency.

Board, E. (2020). No one deserves to die of covid-19 in jail. New York Times. https://www.nytimes. com/2020/04/23/opinion/coronavirus-prisons.html

Bonkiewicz, L., \& Ruback, R. B. (2012). The role of the police in evacuations: Responding to the social impact of a disaster. Police Quarterly, 15(2), 137-156.

Bridgman, A., Merkley, E., Loewen, P. J., Owen, T., Ruths, D., Teichmann, L., \& Zhilin, O. (2020). The causes and consequences of covid-19 misperceptions: Understanding the role of news and social media. The Harvard Kennedy School of Misinformation Review, 1(3), 1-20.

Brown, E. K., \& Socia, K. M. (2017). Twenty-first century punitiveness: Social sources of punitive american views reconsidered. Journal of Quantitative Criminology, 33(4), 935-959.

Callanan, V. J., \& Rosenberger, J. S. (2011). Media and public perceptions of the police: Examining the impact of race and personal experience. Policing \& Society, 21 (2), 167-189.

Campedelli, G. M., Aziani, A., \& Favarin, S. (2020). Exploring the effect of 2019-ncov containment policies on crime: The case of los angeles. arXiv preprint arXiv:2003.11021.

Celestin, B. D., \& Kruschke, J. K. (2019). Lay evaluations of police and civilian use of force: Action severity scales. Law and Human Behavior, 43(3), 290.

Centers for Disease Control \& Prevention. (2020). Cases in the U.S. https://www.cdc.gov/ coronavirus/2019-ncov/cases-updates/cases-in-us.html

Chiricos, T., Welch, K., \& Gertz, M. (2004). Racial typification of crime and support for punitive measures. Criminology, 42(2), 358-390.

Coppock, A. (2019). Generalizing from survey experiments conducted on mechanical turk: A replication approach. Political Science Research and Methods, 7(3), 613-628.

Coppock, A., Leeper, T., \& Mullinix, K. (2018). Generalizability of heterogenous treatment effect estimates across samples. PNAS, 115(49), 12441-12446.

Coyle, J., \& Spencer, T. (2020). Confirmed coronavirus cases are rising in 40 of 50 states. Associated Press. https://apnews.com/0468a60b64947879926d2a16e45c00ee 
Dorfman, L., \& Schiraldi, V. (2001). Off balance: Youth, race $\&$ crime in the news. Building Blocks for Youth.

Drabek, T. E. (1985). Managing the emergency response. Public Administration Review, 45, 85-92.

Drabek, T. E., \& McEntire, D. A. (2002). Emergent phenomena and multiorganizational coordination in disasters: Lessons from the research literature. International Journal of Mass Emergencies and Disasters, 20(2), 197-224.

Drakulich, K. M. (2015). Concerns for self or family? sources of and responses to altruistic fear. Journal of Interpersonal Violence, 30(7), 1168-1207.

Eligon, J., \& MacFarquhar, N. (2020). Coronavirus devastates detroit police, from the chief on down. New York Times. https://www.nytimes.com/2020/04/20/us/coronavirus- detroitpolice.html

Elinson, Z. (2020). Coronavirus has changed everything for police across the country. The Wall Street Journal. https://www.wsj.com/articles / coronavirus-has-changed-everything-forpolice-across-the-country-11588843801

Fan, V., Jamison, D., \& Summers, L. (2018). Pandemic risk: How large are the expected losses? Bulletin of the World Health Organization, 96, 129-134.

Faust, K. L., \& Ven, T. V. (2014). Policing disaster: An analytical review of the literature on policing, disaster, and post-traumatic stress disorder. Sociology Compass, 8(6), 614-626.

Fitzpatrick, K. M., Harris, C., \& Drawve, G. (2020). Fear of covid-19 and the mental health consequences in america. Psychological Trauma: Theory, Research, Practice, and Policy.

Fox, B., Moule Jr, R. K., Jaynes, C. M., \& Parry, M. M. (2020). Are the effects of legitimacy and its components invariant? operationalization and the generality of sunshine and tyler's empowerment hypothesis. Journal of Research in Crime and Delinquency. https://doi.org/ 0022427820926228

Freedman, D. A. et al. (2008). On regression adjustments in experiments with several treatments. The ANNALS of Applied Statistics, 2(1), 176-196.

Geller, A., Fagan, J., \& Tyler, T. (2017). Police contact and mental health. Columbia Public Law Research Paper, (14-571).

Geller, A., Fagan, J., Tyler, T., \& Link, B. G. (2014). Aggressive policing and the mental health of young urban men. American Journal of Public Health, 104(12), 2321-2327.

Gerber, M. M., \& Jackson, J. (2013). Retribution as revenge and retribution as just deserts. Social Justice Research, 26(1), 61-80.

Giorgis, H. (2020). Quarantine could change how americans think of incarceration. The Atlantic. https://www. theatlantic.com/culture/archive/2020/04/ quarantine-could- change- howamericans-think-incarceration/610831/

Gottlieb, A. (2017). The effect of message frames on public attitudes toward criminal justice reform for nonviolent offenses. Crime \& Delinquency, 63(5), 636-656.

Graham, A., Cullen, F., Pickett, J., Jonson, C., Haner, M., \& Sloan, M. (2020). Faith in Trump, moral foundations, and social distancing defiance during the Coronavirus Pandemic. Socius, 6, 1-23. https://doi.org/10.1177/2378023120956815

Graham, J., Haidt, J., \& Nosek, B. A. (2009). Liberals and conservatives rely on different sets of moral foundations. Journal of Personality and Social Psychology, 96 (5), 1029.

Haidt, J. (2012). The righteous mind: Why good people are divided by politics and religion. Vintage.

Hale, C. (1996). Fear of crime: A review of the literature. International Review of Victimology, $4(2), 79-150$.

Hamm, J. A., Trinkner, R., \& Carr, J. D. (2017). Fair process, trust, and cooperation: Moving toward an integrated framework of police legitimacy. Criminal Justice and Behavior, 44(9), $1183-1212$. 
Harris, J. (2020). Us lockdown protests fueled by distrust of government, experts. Courthouse News. https: / / www . courthousenews. com / us- lockdown- protests- fueled- by-distrust- ofgovernment-experts/

Henry, P. J., \& Sears, D. O. (2002). The symbolic racism 2000 scale. Political Psychology, 23(2), $253-283$.

Hinds, L., \& Murphy, K. (2007). Public satisfaction with police: Using procedural justice to improve police legitimacy. Australian \& New Zealand Journal of Criminology, 40(1), 27-42.

Hoskin, M. (2020). The whiteness of anti-lockdown protests. Vox. https://www.vox.com/firstperson/2020/4/25/21234774/coronavirus-covid-19-protest-anti-lockdown

Huddy, L., Feldman, S., Taber, C., \& Lahav, G. (2005). Threat, anxiety, and support of antiterrorism policies. American Journal of Political Science, 49(3), 593-608.

Indermaur, D., Roberts, L., Spiranovic, C., Mackenzie, G., \& Gelb, K. (2012). A matter of judgement: The effect of information and deliberation on public attitudes to punishment. Punishment 85 Society, 14 (2), 147-165.

Intravia, J., Wolff, K. T., \& Piquero, A. R. (2018). Investigating the effects of media consumption on attitudes toward police legitimacy. Deviant Behavior, 39(8), 963-980.

Jackson, J., \& Bradford, B. (2009). Crime, policing and social order: On the expressive nature of public confidence in policing. British Journal of Sociology, 60(3), 493-521.

Jackson, J., Bradford, B., Stanko, B., \& Hohl, K. (2012). Just authority?: Trust in the police in england and wales. Routledge.

Jamieson, K. H., \& Albarracin, D. (2020). The relation between media consumption and misinformation at the outset of the sars-cov-2 pandemic in the us. The Harvard Kennedy School Misinformation Review.

Jennings, W. G., \& Perez, N. M. (2020). The immediate impact of covid-19 on law enforcement in the United States. American Journal of Criminal Justice, 1.

Johnson, D., \& Kuhns, J. B. (2009). Striking out: Race and support for police use of force. Justice Quarterly, 26(3), 592-623.

Jouvenal, J., \& Brice-Saddler, M. (2020). Social distancing enforcement is ramping up. so is concern that black and latino residents may face harsher treatment. The Washington Post. https:// www.washingtonpost.com/local/public-safety/social-distancing-enforcement-is-rampingup-so- is-concern- that-black- and- latino-residents-may-face-harsher-treatment/2020/05/ 10/b1bcf490-8fbd-11ea-9e23-6914ee410a5f_story.html

Kaste, M. (2020). Police back off from social distancing enforcement. NPR. https://www.npr.org/ 2020/05/15/857144397/police-back-off-from-social-distancing-enforcement

Kinder, D. R., Sanders, L. M., \& Sanders, L. M. (1996). Divided by color: Racial politics and democratic ideals. University of Chicago Press.

Larsen, M., \& Olsen, A. (2020). Reducing bias in citizens' perception of crime rates: Evidence from a field experiment on burglary prevalence. The Journal of Politics, 82(2), 747-752.

Levay, K. E., Freese, J., \& Druckman, J. N. (2016). The demographic and political composition of mechanical turk samples. Sage Open, 6(1). https://doi.org/2158244016636433

Lin, W. et al. (2013). Agnostic notes on regression adjustments to experimental data: Reexamining freedman's critique. The ANNALS of Applied Statistics, 7(1), 295-318.

Lum, C., Mapuin, C., \& Stoltz, M. (2020). The impact of covid-19 on law enforcement agencies (wave 1). Center for Evidence-Based Crime Policy.

Lum, C., \& Nagin, D. (2017). Reinventing american policing: A seven-point blueprint for the 21st century. in (michael tonry, ed.) Crime and Justice: A Review of Research, 46(1), 339-393. 
Maguire, E. R., Lowrey, B. V., \& Johnson, D. (2017). Evaluating the relative impact of positive and negative encounters with police: A randomized experiment. Journal of Experimental Criminology, 13(3), 367-391.

Mazerolle, L., Antrobus, E., Bennett, S., \& Tyler, T. R. (2013). Shaping citizen perceptions of police legitimacy: A randomized field trial of procedural justice. Criminology, 51(1), 33-63.

McLean, K., Wolfe, S. E., Rojek, J., Alpert, G. P., \& Smith, M. R. (2020). A randomized controlled trial of social interaction police training. Criminology $\&$ Public Policy, 19(3), 805-832.

Meares, T., \& Tyler, T. (2020). The first step is figuring out what the police are for. The Atlantic. https://www.theatlantic.com/ideas/archive/2020/06/first-step-figuring-out-what-policeare $/ 612793 /$

Mervosh, S., Lu, D., \& Swales, V. (2020). See which states and cities have told residents to stay home. New York Times. https://www.nytimes.com/interactive/2020/us/coronavirus-stayat-home-order.html

Metcalfe, C., \& Pickett, J. T. (2018). The extent and correlates of public support for deterrence reforms and hot spots policing. Law \& Society Review, 52(2), 471-502.

Mohler, G., Bertozzi, A. L., Carter, J., Short, M. B., Sledge, D., Tita, G. E., Uchida, C. D., \& Brantingham, P. J. (2020). Impact of social distancing during covid-19 pandemic on crime in los angeles and indianapolis. Journal of Criminal Justice, 101692.

Moore, T., \& T, L. (2020). Video shows nypd using force during social distancing arrest in brooklyn. New York Post. https://nypost.com/2020/05/04/video-shows-nypd-using-force-duringsocial-distancing-arrest/

Moule Jr, R. K., Burruss, G. W., Parry, M. M., \& Fox, B. (2019). Assessing the direct and indirect effects of legitimacy on public empowerment of police: A study of public support for police militarization in america. Law 85 Society Review, 53(1), 77-107.

Muhammad, K. G. (2010). The condemnation of blackness: Race, crime, and the making of modern urban america, with a new preface. Harvard University Press.

Mullinix, K. J., Leeper, T. J., Druckman, J. N., \& Freese, J. (2015). The generalizability of survey experiments. Journal of Experimental Political Science, 2(2), 109-138.

Mummolo, J. (2018). Militarization fails to enhance police safety or reduce crime but may harm police reputation. Proceedings of the National Academy of Sciences, 115(37), 9181-9186.

Mutz, D. C. (2011). Population-based survey experiments. Princeton University Press.

Nagin, D. S., Solow, R. M., \& Lum, C. (2015). Deterrence, criminal opportunities, and police. Criminology, 53(1), 74-100.

Nagin, D. S., \& Telep, C. W. (2020). Procedural justice and legal compliance: A revisionist perspective. Criminology \& Public Policy, 19(3), 761-786.

Nowotny, K., Bailey, Z., Omori, M., \& Brinkley-Rubinstein, L. (2020). Covid-19 exposes need for progressive criminal justice reform. American Journal of Public Health, 110(7), e1-e2.

Owens, E., Weisburd, D., Amendola, K. L., \& Alpert, G. P. (2018). Can you build a better cop? experimental evidence on supervision, training, and policing in the community. Criminology E Public Policy, 17(1), 41-87.

Parry, M. M., Moule Jr, R. K., \& Dario, L. M. (2019). Technology-mediated exposure to policecitizen encounters: A quasi-experimental assessment of consequences for citizen perceptions. Justice Quarterly, 36(3), 412-436.

Paternoster, R., Brame, R., Mazerolle, P., \& Piquero, A. (1998). Using the correct statistical test for the equality of regression coefficients. Criminology, 36(4), 859-866.

Pedersen, M. J., Stritch, J. M., \& Taggart, G. (2017). Citizen perceptions of procedural fairness and the moderating roles of 'belief in a just world'and 'public service motivation'in public hiring. Public Administration, 95(4), 874-894. 
Peer, E., Vosgerau, J., \& Acquisti, A. (2014). Reputation as a sufficient condition for data quality on amazon mechanical turk. Behavior Research Methods, 46(4), 1023-1031.

Perrin, A., \& Anderson, M. (2019). Share of u.s. adults using social media, including facebook, is mostly unchanged since 2018. Pew Research Center. https://www.pewresearch.org/facttank/2019/04/10/share- of-u-s-adults-using-social-media-including-facebook-is-mostlyunchanged-since-2018/

Peyton, K., Sierra-Arévalo, M., \& Rand, D. G. (2019). A field experiment on community policing and police legitimacy. Proceedings of the National Academy of Sciences, 116(40), 1989419898.

Phillips, K. (2020). Many face mask mandates go unenforced as police feel political, economic pressure. USA Today. https://www.usatoday.com/story/news/politics/2020/09/16/covid19-face-mask-mandates-go- unenforced-police-under-pressure/5714736002/

Pickett, J. T. (2016). On the social foundations for crimmigration: Latino threat and support for expanded police powers. Journal of Quantitative Criminology, 32(1), 103-132.

Pickett, J. T. (2019). Public opinion and criminal justice policy: Theory and research. Annual Review of Criminology, 2, 405-428.

Pickett, J. T., \& Baker, T. (2014). The pragmatic american: Empirical reality or methodological artifact? Criminology, 52(2), 195-222.

Pickett, J. T., Mancini, C., Mears, D. P., \& Gertz, M. (2015). Public (mis) understanding of crime policy: The effects of criminal justice experience and media reliance. Criminal Justice Policy Review, 26(5), 500-522.

Pickett, J. T., Nix, J., \& Roche, S. P. (2018). Testing a social schematic model of police procedural justice. Social Psychology Quarterly, 81(2), 97-125.

Riley, J., \& Ragsdale, T. (2020). Lmpd to no longer respond to hit and run wrecks, other incidents. WDRB News. https://www.wdrb.com/in-depth/lmpd-to-no-longer-respond-to-hit-andrun-wrecks-other-incidents/article_3fa29722-686a-11ea-9ae7-1fcf2d6fb288.html

Ritter, Z. (2020). Americans use social media for covid-19 info, connection. Gallup. https://news. gallup.com/poll/311360/americans-social-media-covid-information-connection.aspx

Roberts, J., Hough, M., Jackson, J., \& Gerber, M. M. (2012). Public opinion towards the lay magistracy and the sentencing council guidelines: The effects of information on attitudes. British Journal of Criminology, 52(6), 1072-1091.

Roberts, J. V., \& Hough, M. (2005). The state of the prisons: Exploring public knowledge and opinion. The Howard Journal of Criminal Justice, 44(3), 286-306.

Roberts, J., \& Stalans, L. (1997). Public opinion, crime, and criminal justice. Westview Press.

Roche, S. P., Pickett, J. T., \& Gertz, M. (2016). The scary world of online news? internet news exposure and public attitudes toward crime and justice. Journal of Quantitative Criminology, 32(2), 215-236.

Rojek, J., \& Smith, M. R. (2007). Law enforcement lessons learned from hurricane katrina. Review of Policy Research, 24(6), 589-608.

Ross, J. (2020). Pattern of uneven social distancing enforcement coming into view, civil rights experts say. NBC News. https://www.nbcnews.com/news/nbcblk/pattern-uneven-socialdistancing-enforcement-coming-view-civil-rights-experts-n1216506

Rummler, O. (2020). Over 5,500 nypd officers return to work after testing positive for coronavirus. Axios. https : / / www . axios . com / coronavirus - nypd - police - 19 bca402 - 58df- 498d - aecae09e14d7a1df.html

Saloner, B., Parish, K., Ward, J. A., DiLaura, G., \& Dolovich, S. (2020). Covid-19 cases and deaths in federal and state prisons. JAMA. https://doi.org/10.1001/jama.2020.12528 
Schaefer, B., \& Hughes, T. (2016). Honing interpersonal necessary tactics (h.i.n.t.): An evaluation of procedural justice training. Southern Police Institute.

Schutten, N. M., Pickett, J. T., Burton, A. L., Cullen, F. T., Jonson, C. L., \& Burton Jr, V. S. (2020). Punishing rampage: Public opinion on sanctions for school shooters. Justice Quarterly, 124.

Shi, L., Lu, Y., \& Pickett, J. T. (2020). The public salience of crime, 1960-2014: Age-period-cohort and time-series analyses. Criminology, 58(3), 568-593.

Silver, J. R. (2017). Moral foundations, intuitions of justice, and the intricacies of punitive sentiment. Law \& Society Review, 51 (2), 413-450.

Silver, J. R., \& Pickett, J. T. (2015). Toward a better understanding of politicized policing attitudes: Conflicted conservatism and support for police use of force. Criminology, 53(4), 650-676.

Skogan, W. G., Van Craen, M., \& Hennessy, C. (2015). Training police for procedural justice. Journal of Experimental Criminology, 11(3), 319-334.

Sloan, M. M., Haner, M., Graham, A., Cullen, F. T., Pickett, J., \& Jonson, C. L. (2020). Pandemic emotions: The extent, correlates, and mental health consequences of personal and altruistic fear of covid-19. https://doi.org/10.31235/osf.io/txqb6

Sommer, W., Branco, E., \& Stein, S. (2020). Trumpists urging people to leave their homes to own the libs. The Daily Beast. https://www.thedailybeast.com/trump-loyalists-and-allies-urgedefiance-of-coronavirus-safety-measures

Southall, A. (2020). Scrutiny of social-distance policing as 35 of 40 arrested are black. New York Times. https: / / www. nytimes.com/2020/05/07/nyregion/nypd-social-distancing-racecoronavirus.html

Stelloh, T. (2020). Video shows nypd officer punching man after alleged social distancing violation. NBC News. https://www.nbcnews.com/news/us-news/video-shows-nypd-officer-punchingman-after-alleged-social-distancing-n1199141

Sunshine, J., \& Tyler, T. R. (2003). The role of procedural justice and legitimacy in shaping public support for policing. Law \& Society Review, 37(3), 513-548.

Surette, R. (2011). Media, crime, and criminal justice: Images, realities, and politics (4th ed.) Wadsworth.

Tabachnick, B., \& Fidell, L. (2001). Using multivariate statistics. Boston: Allyn; Bacon.

Tankebe, J., Reisig, M. D., \& Wang, X. (2016). A multidimensional model of police legitimacy: A cross-cultural assessment. Law and Human Behavior, 40(1), 11.

Thompson, A. J., \& Pickett, J. T. (2019). Are relational inferences from crowdsourced and optin samples generalizable? comparing criminal justice attitudes in the gss and five online samples. Journal of Quantitative Criminology, 1-26.

Travis, J., Western, B., \& Redburn, F. S. (2014). The growth of incarceration in the United States: Exploring causes and consequences. National Academies Press.

Tyler, T. (2004). Enhancing police legitimacy. The ANNALS of the American Academy of Political and Social Science, 593(1), 84-99.

Tyler, T. (2006). Why people obey the law. Princeton University Press.

Tyler, T., \& Boeckmann, R. J. (1997). Three strikes and you are out, but why? the psychology of public support for punishing rule breakers. Law and Society Review, 237-265.

Tyler, T., \& Jackson, J. (2014). Popular legitimacy and the exercise of legal authority: Motivating compliance, cooperation, and engagement. Psychology, Public Policy, and Law, 20(1), 78.

Tyler, T., Mentovich, A., \& Satyavada, S. (2014). What motivates adherence to medical recommendations? the procedural justice approach to gaining deference in the medical arena. Regulation \& Governance, 8(3), 350-370. 
Unnever, J. D., \& Cullen, F. T. (2009). Empathetic identification and punitiveness: A middle-range theory of individual differences. Theoretical Criminology, 13(3), 283-312.

Unnever, J. D., \& Cullen, F. T. (2010). The social sources of americans' punitiveness: A test of three competing models. Criminology, 48(1), 99-129.

Vaughan, T. J., Bell Holleran, L., \& Silver, J. R. (2019). Applying moral foundations theory to the explanation of capital jurors' sentencing decisions. Justice Quarterly, 36(7), 1176-1205.

Vogt, D. (2020). Lmpd responding to burglary alarms again after revising in-person service responses. Wave 3 News. https://www.wave3.com/2020/04/14/lmpd-responding-burglaryalarms-again-after-revising-in-person-service-responses/

Warr, M., \& Ellison, C. G. (2000). Rethinking social reactions to crime: Personal and altruistic fear in family households. American Journal of Sociology, 106(3), 551-578.

Weinberg, J. D., Freese, J., \& McElhattan, D. (2014). Comparing data characteristics and results of an online factorial survey between a population-based and a crowdsource-recruited sample. Sociological Science, 1.

Weitzer, R., \& Tuch, S. A. (2006). Race and policing in america: Conflict and reform. Cambridge University Press.

Williams, T., Weiser, B., \& Rashbaum, W. (2020). Jails are petri dishes': Inmates freed as the virus spreads behind bars. New York Times. https://www.nytimes.com/2020/03/30/us/ coronavirus-prisons-jails.html

Wilson, J. Q. (1978). Varieties of police behavior: The management of law and order in eight communities. Harvard University Press.

Wolfe, S. E., Nix, J., Kaminski, R., \& Rojek, J. (2016). Is the effect of procedural justice on police legitimacy invariant? testing the generality of procedural justice and competing antecedents of legitimacy. Journal of Quantitative Criminology, 32(2), 253-282.

Wood, G., Tyler, T. R., \& Papachristos, A. V. (2020). Procedural justice training reduces police use of force and complaints against officers. Proceedings of the National Academy of Sciences, $117(18), 9815-9821$.

Wozniak, K. H. (2014). American public opinion about prisons. Criminal Justice Review, 39(3), $305-324$. 
Figure 1. Percentage of respondents supporting pandemic policing styles.

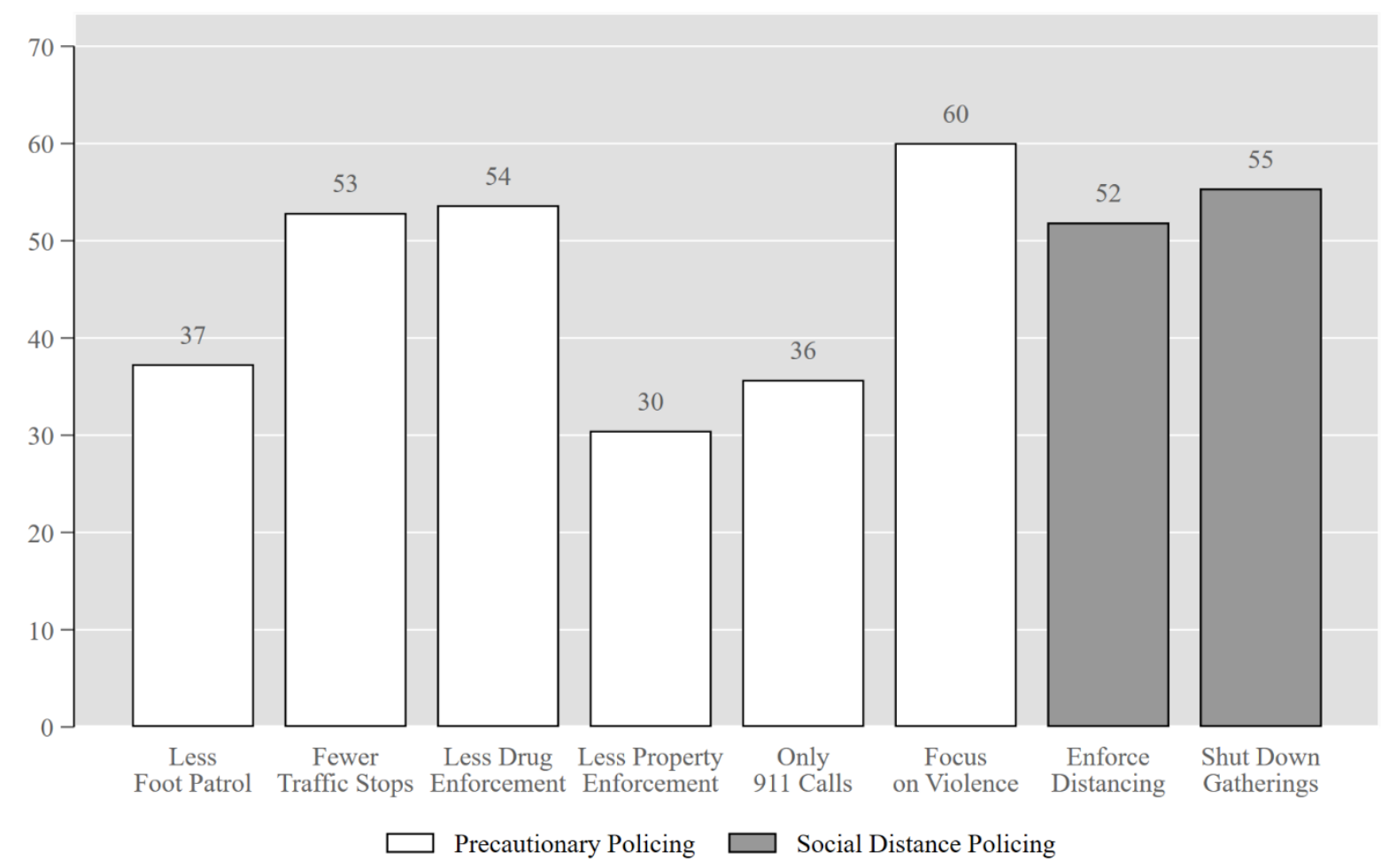

Note: Numbers displayed reflect $\%$ of respondents who support or strongly support each style. 
Table 1. Descriptive Statistics.

\begin{tabular}{|c|c|c|c|c|c|c|}
\hline \multirow[b]{2}{*}{ Variable } & \multicolumn{2}{|c|}{$\begin{array}{l}\text { Control } \\
\text { Condition }\end{array}$} & \multicolumn{2}{|c|}{$\begin{array}{c}\text { Incarceration } \\
\text { Condition }\end{array}$} & \multicolumn{2}{|c|}{$\begin{array}{l}\text { Policing } \\
\text { Condition }\end{array}$} \\
\hline & Mean & $\mathrm{SD}$ & Mean & $\mathrm{SD}$ & Mean & $\mathrm{SD}$ \\
\hline Authoritarian morality & 3.507 & .873 & 3.574 & .805 & 3.499 & .831 \\
\hline Racial resentment & 2.783 & 1.057 & 2.768 & 1.050 & 2.723 & 1.009 \\
\hline Procedural justice & 3.444 & .964 & 3.533 & .969 & 3.544 & 1.009 \\
\hline Personal fear & 2.749 & .863 & 2.802 & .875 & 2.815 & .873 \\
\hline Altruistic fear & 3.289 & .938 & 3.398 & 1.036 & 3.412 & 1.012 \\
\hline White & .787 & - & .789 & - & .763 & - \\
\hline Latino & .120 & - & .138 & - & .117 & - \\
\hline Male & .554 & - & .523 & - & .537 & - \\
\hline Age & 39.633 & 13.333 & 40.012 & 13.411 & 40.172 & 12.673 \\
\hline Married & .569 & - & .569 & - & .572 & - \\
\hline Education & 3.599 & 1.077 & 3.669 & 1.076 & 3.491 & 1.192 \\
\hline Income & 3.111 & 1.251 & 3.196 & 1.224 & 3.150 & 1.356 \\
\hline Employed & .686 & - & .717 & - & .677 & - \\
\hline Republicanism & 2.862 & 1.210 & 2.745 & 1.197 & 2.710 & 1.146 \\
\hline Family victim & .192 & - & .238 & - & .207 & - \\
\hline Attention to COVID & 3.304 & .707 & 3.329 & .759 & 3.380 & .745 \\
\hline
\end{tabular}


Table 2. Pairwise correlations for pandemic policing items.

\begin{tabular}{|c|c|c|c|c|c|c|c|c|}
\hline Item & 1 & 2 & 3 & 4 & 5 & 6 & 7 & 8 \\
\hline 1. Less foot patrol & - & & & & & & & \\
\hline 2. Fewer traffic stops & .470 & - & & & & & & \\
\hline 3. Less drug enforcement & .413 & .495 & - & & & & & \\
\hline 4. Less property enforcement & .467 & .460 & .470 & - & & & & \\
\hline 5. Only 911 calls & .455 & .342 & .274 & .457 & - & & & \\
\hline 6. Focus on violence & .364 & .467 & .440 & .338 & .355 & - & & \\
\hline 7. Enforce social distancing & .212 & .242 & .205 & .247 & .260 & .250 & - & \\
\hline 8. Break up gatherings & .148 & .185 & .221 & .189 & .150 & .250 & .641 & - \\
\hline
\end{tabular}

NOTE: All correlations statistically significant at the .001 level. 
Table 3. Regressions Predicting Support for Precautionary and Social-Distancing Policing During COVID-19 Crisis.

\begin{tabular}{|c|c|c|c|c|c|c|c|c|c|}
\hline \multirow[b]{3}{*}{ Variables } & \multicolumn{4}{|c|}{$\mathrm{DV}=$ Precautionary Policing } & \multicolumn{4}{|c|}{ DV $=$ Social Distance Policing } & \multirow[b]{3}{*}{$Z$} \\
\hline & \multicolumn{2}{|c|}{ Model 1} & \multicolumn{2}{|c|}{ Model 2} & \multicolumn{2}{|c|}{ Model 3} & \multicolumn{2}{|c|}{ Model 4} & \\
\hline & $b$ & $\mathrm{SE}$ & $b$ & SE & $b$ & SE & $b$ & $\mathrm{SE}$ & \\
\hline \multicolumn{10}{|l|}{ Experimental manipulation } \\
\hline Control (reference) & - & - & - & - & - & - & - & - & - \\
\hline Inmate health prime & .025 & .077 & .045 & .073 & .069 & .077 & .037 & .069 & .080 \\
\hline Police health prime & $.203^{* *}$ & .076 & $.170^{*}$ & .073 & .133 & .075 & .077 & .070 & .920 \\
\hline Authoritarian morality & - & - & $-.152^{* * *}$ & .046 & - & - & .080 & .048 & $3.490 * * *$ \\
\hline Racial resentment & - & - & $-.144^{* * *}$ & .039 & - & - & $-.139 * * *$ & .039 & .091 \\
\hline Procedural justice & - & - & .057 & .037 & - & - & $.113^{* *}$ & .036 & 1.085 \\
\hline Personal fear & - & - & $-.134^{* * *}$ & .040 & - & - & .054 & .040 & $3.323^{* * *}$ \\
\hline Altruistic fear & - & - & $.220 * * *$ & .039 & - & - & $.303^{* * *}$ & .037 & 1.544 \\
\hline White & - & - & $.181^{*}$ & .078 & - & - & -.141 & .072 & $3.033^{* *}$ \\
\hline Latino & - & - & .031 & .104 & - & - & -.031 & .098 & .434 \\
\hline Male & - & - & .023 & .062 & - & - & -.100 & .059 & 1.437 \\
\hline Age & - & - & $-.013^{* * *}$ & .002 & - & - & $-.005^{*}$ & .002 & $2.828^{* *}$ \\
\hline Married & - & - & .072 & .066 & - & - & .041 & .063 & .340 \\
\hline Education & - & - & -.043 & .030 & - & - & -.004 & .028 & .950 \\
\hline Income & - & - & -.040 & .026 & - & - & .029 & .025 & .305 \\
\hline Employed & - & - & -.074 & .068 & - & - & -.030 & .064 & .471 \\
\hline Republicanism & - & - & .023 & .030 & - & - & $-.057^{*}$ & .029 & 1.917 \\
\hline Family victim & - & - & -.045 & .075 & - & - & $-.215^{* *}$ & .072 & 1.635 \\
\hline Attention to COVID news & - & - & .051 & .042 & - & - & .051 & .044 & .000 \\
\hline$R^{2}$ & \multicolumn{2}{|c|}{.008} & \multicolumn{2}{|c|}{.139} & \multicolumn{2}{|c|}{.003} & \multicolumn{2}{|c|}{.219} & - \\
\hline$N$ & \multicolumn{2}{|c|}{1,015} & \multicolumn{2}{|c|}{987} & \multicolumn{2}{|c|}{1,015} & \multicolumn{2}{|c|}{987} & - \\
\hline
\end{tabular}

NOTE: Both dependent variables are standardized mean indices.

ABBREVIATIONS: $b=$ unstandardized coefficient; SE = robust standard error, $Z=$ slope-difference test for full models.

${ }^{*} \mathrm{p}<.05 ;{ }^{* *} \mathrm{p}<.01 ;{ }^{* * *} \mathrm{p}<.001$ (two-tailed). 